İmre Ersoy ${ }^{1}$

UDK 658.148(560)

330.101.541:330.43>(560)

Original scientific paper

Izvorni znanstveni rad

\title{
THE IMPACT OF FINANCIAL OPENNESS ON FINANCIAL DEVELOPMENT, GROWTH AND VOLATILITY IN TURKEY: EVIDENCE FROM THE ARDL BOUNDS TESTS
}

\begin{abstract}
The aim of this paper is to investigate the impact of financial openness on financial development, growth and output volatility in Turkey. Results of the bounds test reveal that financial openness is in a long run equilibrium relationship with financial development, growth and output volatility. Granger causality tests disclose the existence of unidirectional causality from financial development to financial openness in the long run and from financial openness to output volatility in the short run. Yet, no Granger causality is detected neither from financial openness to growth nor from financial openness to financial development. Results call for further financial development and more conscientious monetary and fiscal policy design for financial openness in Turkey.
\end{abstract}

Key words: International Investment; Long Term Capital Movements; Short Term Capital Movements; Open Economy Macroeconomics; Economic Growth of Open Economies; Bounds test; Granger causality

Jel Classification: F21; F32; F41; F43; C32

\section{INTRODUCTION}

Financial openness is achieved by removing impediments to cross-border flow of capital and financial services; by broadening and deepening of cross border financial ties and by removing less favorable treatment to foreign investors and foreign capital (Herrero and Wooldridge, 2007). The cross border financial asset holdings that were less than half of world GDP by 1970s has reached to over 3 times of the world GDP by mid-2000s. Financial openness, according to standard economic theory, is assumed to provide lower cost of financing, efficient allocation of resources, international risk sharing, increase in investments, financial development and growth. The emerging market economies (EMEs) started to open their capital accounts after mid-1980s with the main aim of attracting capital to grow, following the globalization trend prevalent in the developed world.

Financial openness, in the mean time, increased the vulnerability of EMEs to financial crises mainly through sudden stops, capital flow reversals and contagion which created "liquidity constraints" in the host country due to "flight to quality (liquidity)" and impaired

Corresponding address: Imre Ersoy, Marmara University, European Union Institute, Department of European Union Economics, Göztepe Campus 347-22 Kadıköy, İstanbul TURKEY.E-mail: iersoy@marmara.edu.tr 
growth. The pro-cyclical "capital flow bonanzas" driven by the scarcity of capital and high remuneration in EMEs due to their catching up process has been the major culprit of the boom and bust cycles particularly in East Asia in 1997, Russia in 1998 and in Turkey, Argentina, Brazil in 2001 and 2002. The recent global financial turmoil has also led EMEs to face "sudden stops" due to deleveraging of positions in advanced countries.

There is no consensus on whether the risks of increased financial integration in terms of more volatility introduced, outweigh the benefits. The openness-growth nexus also provide inconclusive results for the EMEs. However, financial development level is considered as an important indicator for the cost-benefits trade-off from financial openness. Financial development is measured by the size, depth, access, efficiency and stability of the markets, intermediaries, assets, institutions and regulations of the financial system (Roubini and Bilodeau, 2009). The impact of financial openness on financial development is important as financial development is empirically proven to drive growth, both in the developed world and in the developing (i.e. King and Levine, 1993; Levine, 2004; Soukhakian, 2007; Katırcıoğlu, Kahyalar and Benar, 2007).

The first steps of financial liberalization started by 1980 in Turkey with the structural adjustment program that aimed financial liberalization besides export-led growth. The period then after is marked by deregulation of financial markets, trade liberalization, de jure ${ }^{2}$ capital account liberalization, establishment of organized money, foreign exchange and stock exchange markets, followed by a final step of capital account liberalization with Decree No.32, in 1989 (Esen, 2000). Yet, the first financial crisis that hit Turkey after the financial openness was in 1994. 1998 was also a drastic year due to contagious effects of the crises in East Asia and Russia. However, the most devastating crisis, due also to the existing distortions and weak institutional settings, was in 2001 in Turkey. The period after 2002 is marked with banking sector restructuring, more stable economic outlook in line with the global developments and high FDI inflows until the global financial crisis. On the other hand, Turkey has developing financial markets, with total financial assets of $130 \%$ of its GDP and ranks $44^{\text {th }}$ amongst 54 countries as of 2007, in the Financial Development Index of Roubini and Bilodeau (2009). The securitization and derivatives markets are almost inexistent and the private bond issuances, which are detrimental for financial development, account for $0.1 \%$ of Turkey's GDP (Beck and Demirgüç - Kunt, 2009); whereas 70\% of the Turkish stock exchange market shares belongs to foreigners.

The aim of this paper is to investigate the impact of financial openness on the financial development, growth and output volatility of Turkey. To that end, the paper employs the bounds test for cointegration, to search if financial openness is in a long run equilibrium relationship with financial development, growth and output volatility. On the other hand, Granger causality tests are employed to investigate the direction of causality between financial openness and financial development, growth and output volatility in Turkey.

The paper is motivated, to the best knowledge of the author, by the following voids in the literature: First, the inconclusiveness on the openness - growth nexus necessitates the topic to be scrutinized on the country level. Second, this paper investigates the long-run relationship and direction of causality between financial openness and financial development and also between financial openness and volatility that have not been researched so far for Turkey. Last but not least, this paper investigates the relation between financial openness and financial development, growth and output volatility by employing Bounds test for cointegration within the ARDL (Autoregressive Distributed Lag) modeling approach.

\footnotetext{
${ }^{2}$ De jure measures of financial openness show the regulatory state of financial openness (i.e. the index of Chin and Ito, 2008). De facto measures, on the other hand, are quantity-based capital account openness measures.
} 
The rest of the paper unfolds as follows: Section 2 reviews the literature. Section 3 describes the data and the methodology for the empirical analyses. Section 4 discusses the empirical results. Section 5 comments on policy implications and concludes.

\section{LITERATURE REVIEW}

The empirical literature on the drivers of financial openness generally point out to trade openness, financial development level and economic growth. To cite only a few; Vo and Daly (2007) in their analysis of 79 developed and developing countries for 1980 - 2003 find that international financial integration has a positive relationship with rich and well-educated countries, trade openness, financial development level, soundness of the banking system and economic growth and a negative relationship with capital control measures, inflation and taxes. Lane and Milesi-Ferretti (2008) empirically prove that international financial integration is strongly and positively correlated with financial development, being a financial centre, economic growth and lower home bias; positively but not as strongly correlated with trade.

The literature on openness-growth nexus is rich, albeit inconclusive. ${ }^{3}$ Edwards (2001), by employing Quinn index, proves that financial globalization enhances growth in countries that are financially developed. Aizenman, Pinto and Radziwill (2007) show that no evidence of growth is associated with increases in the share of portfolio investments in developing countries. Prasad, Rajan and Subramanian (2007) also confirm a negative relationship between growth and foreign capital. Butkiewicz and Yanıkkaya (2008) provide, however, evidence that FDI and equity flows have a positive effect on growth both in developed and developing countries; whereas volatile short term flows hinder growth and that capital account liberalization enhances growth especially in developed countries. Yet, Gamra (2009) demonstrates that domestic financial liberalization has a positive, stock market openness has an insignificant, capital account liberalization has a strong negative, full liberalization has a negative whereas partial liberalization has a positive impact on growth. Rodrik and Subramanian (2009) suggest, on the other hand, that if FDI is accompanied by capital inflows then the distinction between the two becomes less important due to the exchange rate appreciation they both introduce.

For the effect of financial openness on volatility, Frankel and Cavallo (2004) find that financial openness has insignificant and negative relationship with sudden stops, whereas Calvo, Izquierdo and Mejia (2004) find a positive relationship. Edwards (2007) finds that financial openness has a negligible positive impact on the probability of "capital flow contractions" (CFC) ${ }^{4}$ whereas a higher FDI to GDP ratio has a negative impact on CFC. On the other hand, Nicolo and Juvenal (2010) empirically demonstrate that advances in financial integration from 1985 to 2009 had a positive relationship with financial development, equity market liquidity, higher growth, lower growth volatility and lower probability of risk both in advanced countries and EMEs. Umutlu, Akdeniz and Altay-Salih (2010) also document a negative relationship between financial openness and aggregated stock exchange volatility and assert that to decrease volatility; the investor base should be broadened in stock exchange markets. Aizenman, Chinn and Ito (2010) find that high levels of financial openness, when

\footnotetext{
3 Edwards (2007) claim that the difficulties in measuring the level of capital mobility caused unhealthy empirical results. Schindler (2009) advocates that the reason for inconclusiveness is the scarcity of de jure financial globalization indexes which are under the control of policymakers. Butkiewicz and Yanıkkaya (2008) attribute the inconclusiveness to the measurement of short and long-term capital flows together.

${ }_{4}$ CFC is defined as abrupt declines of 3\% of GDP in capital inflows per year, taking also into account the sudden stops and capital flights.
} 
only coupled with high levels of financial development reduces output volatility in EMEs but developing countries which are net receivers of hot money, in the form of cross country bank lending or portfolio flows, experience high output volatility.

For the relationship between financial openness and financial development, Baltagi, Demetriades and Hook (2009) find that in lower income countries, the marginal impact of financial openness on financial development is high, whereas financial development through additional financial integration in already open ones is proved to be limited. Baltagi, Demetriades and Hook (2009) empirically demonstrate that banking sector development has a positive relationship with financial openness and with trade openness, independently, both for developing and industrialized countries. Their result partially contradicts Rajan and Zingales (2003) who suggest that for financial development, both financial openness and trade openness are prerequisites due mainly to political economy reasons.

On the other hand, some empirical studies provide evidence that host countries must be at a certain development level to benefit from financial openness. Mishkin (2006) suggests that there are prerequisites to be able to reap the benefits of financial globalization, including developing strong property rights, improving corporate governance, reducing corruption, strengthening the legal system. However, the response of Rodrik and Subramanian (2009) to this argument is that; the developing countries that manage successfully these reforms will no more be poor and financial globalization would then be dispensable. Yet, a new literature on financial openness suggests that the indirect benefits of financial openness are more important than the inconclusive growth enhancing role of financial openness. Köse, Prasad, Rogoff and Wei (2009) argue that financial globalization have collateral-benefits, in other words indirect effects like financial development, institutional development and macroeconomic discipline. Furthermore Köse, Prasad, Taylor (2010) claim that countries can reduce the risks of financial openness and reap these indirect benefits only after reaching a certain quantifiable threshold level of financial and institutional development, which are lower for FDI and portfolio equity liabilities but higher for debt liabilities. Köse et al. (2010) empirically provide evidence for certain quantifiable threshold levels after the breach of which, the merits of financial openness in terms of growth and the cost-benefit trade-off from financial openness improves considerably.

For Turkey, Katırcıoglu (2009) investigates the long-run equilibrium relationship and the direction of causality between FDI inflows and real GDP by employing ARDL bounds testing approach and Granger causality tests. Results of the empirical analysis for the period of 1970 - 2005 suggest the existence of cointegration only when FDI inflows are the dependent variable and unidirectional causality that runs from real GDP growth to FDI inflows in Turkey. Klasra (2011) investigates the existence of long run equilibrium relationship and direction of Granger causality between foreign direct investment, trade openness and economic growth during the periods of 1975-2004 for Pakistan and Turkey. The results of the empirical analyses depict no Granger causality running between FDI and growth. Özdemir and Erbil (2008) analyze the impact of financial openness on per capita income and growth of 10 new EU members and Turkey by employing quarterly longitudinal panel for the period of 1995 - 2007. Their analysis suggests that financial openness is negatively associated with growth in Turkey. Ilgun, Koch and Orhan (2010) establish a VAR Model to examine the FDI-Growth relation and also run impulse-response, variance decomposition analyses and Wald statistic for the causality test between 1980 and 2004. They find, in contrast to the existing literature, a bi-directional causality between FDI and growth in Turkey in their model where they assume a Cobb-Douglas production function but deviate from the standard literature by using $A$ for the factors that impact growth including FDI.

This study is different from the existing literature on Turkey in three respects: First, the existing literature investigates only the relationship between financial openness and 
growth, whereas this study investigates the impact of financial openness on financial development, growth and output volatility. Second, this study investigates financial openness by taking into account FDI inflows, FDI outflows and net portfolio investments; whereas Katırcioğlu (2009) and Ilgun et al. (2010) concentrates only on FDI inflows and Klasra (2011) only on FDI. Yet, their empirical findings lend support to the findings of this study. Third, this study is different from Özdemir and Erbil (2008) as it employs ARDL bounds testing for level relationship and Granger causality for direction of causality between financial openness and growth.

The inconclusiveness in the literature on the openness - growth nexus as well as the importance of the relationship between financial openness and volatility and between financial openness and financial development render the empirical scrutiny of a country level analysis indispensable for Turkey.

\section{DATA AND METHODOLOGY}

The paper employs annual data covering the period from 1980 to 2008. The data source for all the variables employed is the World Development Indicators (WDI, 2010). Financial openness (FO) is calculated as the sum of FDI net inflows, FDI net outflows and net portfolio investments to GDP. For financial development (FDP), M2/ GDP is used which stands for the ratio of liquid liabilities (currency, demand and interest bearing liabilities of banks and other financial intermediaries) to GDP. FDP is a measure of the overall size of the financial intermediary sector and is used as a traditional indicator of financial depth since the seminal work of King and Levine (1993). Real gross domestic product (GDP) is used to proxy for growth. For output volatility (V-GDP), the 5 year rolling standard deviation of real GDP growth rate is calculated as also employed by Jalil, Ma and Naveed (2008). The variables FO, FDP, GDP and v-GDP are in their natural logs.

The paper employs the Augmented Dickey \& Fuller (ADF) and Phillips \& Perron (PP) unit root tests to search for the integration level between FO, FDP, GDP and v-GDP. ${ }^{5}$ The integration level is searched to verify that the variables are not integrated of order two, I (2).

Then, the bounds test for cointegration within the Autoregressive Distributed Lag (ARDL) modeling approach developed by Pesaran, Shin and Smith (2001) is employed to investigate if FO is in a long-run relationship with FDP, GDP and v-GDP. The ARDL modeling approach can be employed irrespective of whether regressors are purely I (0), purely I (1) or mutually co-integrated. The ARDL modeling approach involves estimating the following error correction models: ${ }^{6}$

$$
\begin{aligned}
& \Delta \ln Y_{t}=a_{0_{Y}}+\sum_{i=1}^{n} b_{i_{Y}} \Delta \ln Y_{t-i}+\sum_{i=0}^{n} c_{i_{Y}} \Delta \ln X_{t-i}+\sigma_{1_{Y}} \ln Y_{t-1}+\sigma_{2_{Y}} \ln X_{t-i}+\varepsilon_{1 t} \\
& \Delta \ln X_{t}=a_{0_{X}}+\sum_{i=1}^{n} b_{i_{X}} \Delta \ln X_{t-i}+\sum_{i=0}^{n} c_{i_{X}} \Delta \ln Y_{t-i}+\varpi_{1_{X}} \ln X_{t-1}+\varpi_{2_{X}} \ln Y_{t-i}+\varepsilon_{2 t}
\end{aligned}
$$

In equations 1 and $2, \Delta$ is the difference operator; $\varepsilon_{\mathbf{1 t}}$ and $\varepsilon_{\boldsymbol{z} t}$ are serially independent random errors with mean zero and finite covariance matrix. In the above equation with $Y$ as the dependent variable, the null hypothesis of no cointegration is $H_{0}: \mathrm{C}_{1}\left(1_{1} Y\right)=\mathrm{G}_{1}\left(2_{1} Y\right)=$

\footnotetext{
5 The PP unit root test is applied besides ADF as it computes a residual variance that is robust to autocorrelation.

6 Formatting and styles of equations and tables 1 to 4 and even some notations heavily draw from the various publications of Katırcıoğlu, S.T. (i.e. Katircioglu and Yorucu 2010) who, amongst his other publications, created an extensive literature on Bounds testing for cointegration.
} 
0 and the alternative hypothesis of co-integration is $H_{1}: \mathrm{G}_{1}\left(\mathbf{1}_{1} Y\right) \neq \mathrm{G}_{1}\left(2_{1} Y\right) \neq 0$. In the second equation with $\mathrm{X}$ as the dependent variable, the null hypothesis of no cointegration is $H_{0}: G_{1} 1 Y=G_{1} 2 Y=0$ and the alternative hypothesis of co-integration is $H_{1}: G_{1}\left(1_{1} Y\right) \neq$ $\left(2_{1} Y\right) \neq 0$.

As the next step, the paper runs the Granger causality tests under the vector error correction model (VECM) for the cointegrated variables. In the absence of cointegration, the Granger causality tests are run under the vector autoregressive (VAR) model. Hence, the VAR model in equation 3 and the VECM in equation 4 can be expressed as follows:

$$
\Delta \ln Y_{t}=\alpha_{0}+\varphi_{11}^{p}(L) \Delta \ln Y_{t}+\varphi_{12}^{q}(L) \Delta \ln X_{t}+u_{1 t}
$$

$$
\Delta \ln X_{t}=\alpha_{1}+\varphi_{21}^{p}(L) \Delta \ln X_{t}+\varphi_{22}^{q}(L) \Delta \ln Y_{t}+\delta E C T_{t-1}+u_{2 t}
$$

where,

$$
\varphi_{i j}^{p}(L)=\sum_{n=1}^{P_{i j}} \varphi_{i j n} L^{1} \quad \varphi_{i j}^{q}(L)=\sum_{n=1}^{q_{i j}} \varphi_{i j n} L^{1}
$$

$$
\varphi_{21}^{p}(L)=\sum_{i=1}^{P_{21}} \varphi_{21, i}^{p} L^{i} \quad \varphi_{22}^{p}(L)=\sum_{i=0}^{q_{22}} \varphi_{22, i}^{p} L^{i}
$$

In equations (3) and (4), $\boldsymbol{\Delta}$ symbolizes the difference operator and L symbolizes the lag operator where (L) $\Delta \ln Y_{t}=\Delta \ln Y_{t-1}$. On the other hand, $u_{\mathbf{1 t}}$ and $u_{\mathbf{z} t}$ are serially independent random errors with mean zero and finite covariance matrix. $E C T_{t-1}$ is the lagged error correction term derived from the long-run cointegration model. For Granger causality under VECM, the $\mathrm{F}$ and t-test statistics for $E C T_{t-1}$ in equation 4 should be statistically significant to infer causality from $\mathrm{Y}$ to $\mathrm{X}$. In the case of VAR in equation 3, the statistical significance of only the $\mathrm{F}$ test is enough to infer short-run Granger causality from $\mathrm{X}$ to $\mathrm{Y}$.

\section{RESULTS AND DISCUSSIONS}

Table 1 illustrates ADF and PP unit root test results for FO, FDP, GDP and v-GDP. FO is stationary at level, or in other words, integrated of order zero, I (0). FDP, GDP and vGDP are stationary at first differences, I (1) according to both the ADF and the PP tests.

As the second step, the bounds test within the ARDL modeling approach is applied irrespective of whether regressors are purely I (0), purely I (1) or mutually co-integrated, to investigate if FO is in a long run equilibrium relationship with FDP, GDP and v-GDP. Table 2 depicts the critical values for $F$ and $t$ statistics that are taken from Pesaran et al. (2001). The calculated F-statistics value is compared with two sets of critical values estimated by Pesaran et al. (2001), one assuming that all variables are $\mathrm{I}(0)$ and the other assuming that they are all $\mathrm{I}(1)$.

Table 3 demonstrates the results of the bounds test for cointegration for each pair of dependent variable and its regressor for three different scenarios of Pesaran et al. (2001). FIII is the first scenario without deterministic trends and unrestricted intercepts. FIV is with restricted deterministic trends and unrestricted intercepts. Finally, FV is the scenario with unrestricted deterministic trends and unrestricted intercepts.

Results in Table 3 depict that the application of the bounds $\mathbf{F}$-test using ARDL modeling approach suggests the existence of long-run equilibrium relationships as $\mathbf{F}$ statistics exceed the upper critical value and the null hypotheses of $H_{0}: \mathbf{C}_{1}\left(1_{1} Y\right)=\mathrm{C}_{1}\left(2_{1} Y\right)=$ 0 and of $H_{0}:{ }_{1} 1 Y={ }_{1} 2 Y=0$ are rejected at $0.10,0.05$ or 0.01 levels except for the cases when FDP and v-GDP are the dependent variables. There is a long-run equilibrium relationship between each pair of dependent variable and its regressor, with the above 
mentioned exceptions. Yet, the results of the bounds test for cointegration under the ARDL approach reveal that financial openness is in a long-run equilibrium relationship with financial development, real GDP growth and output volatility in Turkey. The result from the application of the bounds t-test of each ARDL model also shows that trend restrictions may be imposed in (FO/FDP), (FO/GDP) and (FO/v-GDP) relationships according to the significance of the t-statistics.

As the last step, the Granger causality tests are run under the VECM for the cointegrated variables and under the VAR model for variables that are not cointegrated, to search for the direction of causality. The Granger causality tests are run for up to 3 lags to ensure that the results are not sensitive to lag length choice as suggested by Pindyck and Rubinfeld, (1991). Results of the VECM under ARDL in Table 4 suggest unidirectional causality from FDP to FO. Whereas, results of the VAR model in Table 4 suggests short-run causality running from FO to v-GDP.

\section{CONCLUDING REMARKS AND POLICY IMPLICATIONS}

This study investigates the impact of financial openness on financial development, growth and output volatility in an EME that started financial globalization by mid-1980s and lived through recurrent financial crisis particularly since mid-1990s. This analysis is even more important today because the global financial crisis refueled the debate on the costs and merits of financial openness. Results of the bounds test reveal that financial openness is in a long run equilibrium relationship with financial development, growth and output volatility in Turkey. Granger causality tests, on the other hand, disclose the existence of unidirectional causality running from financial development to financial openness in the long run and from financial openness to output volatility in the short run. Yet, no Granger causality is detected neither from financial openness to growth nor from financial openness to financial development in Turkey.

The findings of this study call for more conscientious and proactive monetary and fiscal policy design for financial openness and further development of financial markets in Turkey. First, it seems that the Central Bank of Turkey should implement even more proactive monetary policy measures to dampen the output volatility induced by the non growth enhancing short term portfolio investment inflows. Second, it seems that for financial openness to impact growth positively, fiscal incentives should be introduced i.e. to encourage that the profits of FDIs are kept in Turkey for certain durations rather than their immediate transfer back to the home countries. Third, it seems that incentives should be introduced in line with the suggestions of Umutlu et al. (2010) to broaden the investor base in the Turkish financial markets to dampen the volatility stimulated by financial openness. Fourth, it seems that it should be spotted by the policy makers that Turkey needs to have more developed financial markets particularly due to the empirical findings of Köse et al. (2010), who assert that a certain threshold level of financial development is necessary for financial openness to impact the growth of a country positively. To that end, fiscal incentives may be introduced to limit the increasing shares of local currency denominated domestic public debt in Turkish banks' portfolios that negatively affect financial development (Ersoy, 2011). Last but not least, the only long run causality detected in this study shows that the level of financial development attained after opening up of the financial markets stimulates FDI and net portfolio investment inflows to Turkey. This is important as Turkey is a capital constraint country. Yet, the second causality detected in this study that runs in the short term from financial openness to output volatility should be recognized as the cost of these financial inflows that replace for savings in Turkey. 


\section{ACKNOWLEDGEMENTS}

The author gratefully acknowledges Prof. Salih Katırcıoglu $(\mathrm{PhD})$ and the unanimous referees for their invaluable comments. Usual disclaimers hold.

\section{REFERENCES}

Aizenman, J.; Chinn, M. and Ito, H. (2010): “The emerging global financial architecture: Tracing and evaluating new patterns of the trilemma configuration", Journal of International Money and Finance, 29(4):615-641.

Aizenman,J., Pinto,B. and Radziwill, A. (2007): "Sources for financing domestic capital - Is foreign saving a viable option for developing countries?”, Journal of International Money and Finance, 26(5): 682-702.

Baltagi, B. H., Demetriades, P.O. and Hook, S. L. (2009): "New Approaches to Financial Globalization Financial development and openness: Evidence from panel data," Journal of Development Economics 89(2):285-296.

Beck, T., Demirgüç - Kunt, A. (2009): "Financial Institutions and Markets across Countries and Over Time - Data and Analysis”, World Bank Policy Research Working Paper 4943, World Bank, Washington.

Butkiewicz, J. and Yanıkkaya, H. (2008): "Capital Account Openness, International Trade and Economic Growth: A Cross-Country Empirical Investigation,” Emerging Markets Finance \& Trade, March-April 2008.

Calvo, G.A., Izquierdo, A. and Mejia, L.F., (2004): "On the empirics of sudden stops: the relevance of balance-sheet effects” NBER Working Paper No. 10520, National Bureau of Economic Research, Cambridge

Chin, M. and Ito, H. (2008): “A New Measure of Financial Openness," Journal of Comparative Policy Analysis, 10(3):309-322.

Edwards, S. (2007): "Capital controls, capital flow contractions and macroeconomic vulnerability,” Journal of International Money and Finance 26 (2007):814-840.

Edwards, S. (2001): "Capital Mobility and Economic Performance: Are Emerging Economies Different?” NBER Working Paper Series 8076, National Bureau of Economic Research, Cambridge.

Ersoy, İ. (2011): “Government Debt vs. Financial Depth dilemma in developing countries: the case of Turkey," Acta Oeconomica, forthcoming.

Esen, O. (2000): "Financial Openness in Turkey," International Review of Applied Economics, 14(1):2000.

Gamra, S.B. (2009): "Does financial liberalization matter for Emerging East Asian economies growth? Some new evidence,” International Review of Economics and Finance, 18(3):392403.

Frankel, J. and Cavallo, E. (2004): "Does Openness to Trade Make Countries More Vulnerable to Sudden Stops or Less? Using Gravity to Establish Causality,” NBER Working Paper: 10957, National Bureau of Economic Research, Cambridge.

Herrero, A. G. and Wooldridge, P. (2007): "Global and regional financial integration: progress in emerging markets,” BIS Quarterly Review, September 2007.

Ilgun,E; Koch, K-J and Orhan, M.(2010): "How Do Foreign Direct Investment and Growth Interact in Turkey?” Eurasian Journal of Business and Economics 3 (6): 41-55.

Jalil, A., Ma, Y. and Naveed, A. (2008): “The Finance-Fluctuation Nexus: Further Evidence from Pakistan and China," International Research Journal of Finance and Economics 14(2008):212-231. 
Katircioglu, S. and Yorucu, V. (2010), “The Bounds Test Approach for Co-integration and Causality between International Trade, International Tourism and Economic Growth: The Case of Turkey," Applied Economics (Forthcoming).

Katırcıoğlu, S. T. (2009) "Foreign Direct Investment and Economic Growth in Turkey: An Empirical Investigation by the Bounds Test for Co-integration and Causality Tests”, Economic Research, 22(2009):3.

Katircioglu, S.T., Kahyalar, N. and Benar, H. (2007): "Financial development, trade and growth triangle: the case of India", International Journal of Social Economics, 34 (9):586 $-598$.

King, R.G., Levine, R. (1993): “Finance and Growth: Schumpeter Might be Right”, Quarterly Journal of Economics, 108(3):717-737.

Klasra, M.A. (2011): "Foreign Direct Investment, trade openness and economic growth in Pakistan and Turkey: an investigation using bounds test," Quality and Quantity, 45(1):223231.

Kose, M.A., Prasad, E., Rogoff, K. And Wei, S-J. (2009): "Financial Globalization: A Reappraisal,” IMF Staff Papers 56(2009):1, International Monetary Fund, Washington D.C.

Kose, M. A; Prasad, E.S; Taylor, A.D. (2010): "Thresholds in the Process of International Financial Integration,” Journal of International Money and Finance, 30(1):147-179

Lane, P and Milesi-Ferretti, G. M. (2008): “The Drivers of Financial Globalization,” American Economic Review, 98(2):327-332.

Levine, R. (2004): "Finance and Growth: Theory and Evidence" NBER Working Paper 10766, National Bureau of Economic Research, Cambridge.

Mishkin, F. (2006): "Is Financial Globalization Beneficial," Journal of Money, Credit and Banking, 39(2-3):259-294

Nicolo G. and Juvenal, L. (2010): "Financial Integration, Globalization, Growth and Systemic Real Risk” Federal Reserve Bank of St. Louis, October, 2010.

Özdemir, D. and Erbil, C. (2008): "Economic Growth? Evidence from Turkey and Other Recent EU Members,” Eco Mod International Conference on Policy Modeling, Berlin, Germany, July 2-4, 2008

Pesaran, M. H., Shin, Y. and Smith, R. J. (2001): "Bounds Testing Approaches to the Analysis of Level Relationships”, Journal of Applied Econometrics, 16: 289-326.

Pindyck, R. S. and Rubinfeld, D. L. (1991): Models and Economic Forecasts, McGraw-Hill Inc.

Prasad, E., Rajan, R. and Subramanian, A. (2007): “The Paradox of Capital,” A compilation of articles from Finance and Development by IMF under Financial Globalization: The impact on trade, policy, labor and capital flows" International Monetary Fund, Washington D.C.

Rajan, R.G. and Zingales, L. (2003): "The great reversals: the politics of financial development in the twentieth century," Journal of Financial Economics, 69 (1), 5-50.

Rodrik, D. and Subramanian, A. (2009): "Why Did Financial Globalization Disappoint?”IMF Staff Papers, 56(1):112, International Monetary Fund, Washington D.C.

Roubini, N., Bilodeau, J. (2009): "The Financial Development Index: Taking Stock of Financial System Strength in a Time of Crisis,” The Financial Development Report 2009, Edited by Roubini, N., Bilodeau, J., World Economic Forum USA Inc. ISBN-10: 9295044-27-4

Schindler, M. (2009): "Measuring Financial Integration: A New Dataset," IMF Staff Papers 56(1), International Monetary Fund, Washington, D.C. 
Soukhakian, B. (2007): "Financial Development, Trade Openness and Economic Growth in Japan: Evidence from Granger Causality Tests”, International Journal of Economic Perspectives,1(3):118-27.

Umutlu, M.; Akdeniz, L. and Altay-Salih, A. (2010):“The degree of financial liberalization and aggregated stock-return volatility in emerging markets," Journal of Banking and Finance, 34(3):509-521.

Vo, X. V. and Daly, K. J. (2007): “The determinants of international financial integration," Global Finance Journal 18(2):228-250.

WDI (2010): World Development Indicators, World Bank, Washington D.C.

\section{ANNEX:}

Table 1: ADF and PP Tests for Unit Root

\begin{tabular}{lllllllll}
\hline Statistics (Levels) & lfo & lag & lfdp & lag & lgdp & lag & lvgdp & lag \\
\hline$\tau_{\mathrm{T}}(\mathrm{ADF})$ & $-4.35^{*}$ & $(0)$ & -2.92 & $(0)$ & -2.55 & $(0)$ & -1.77 & $(0)$ \\
$\tau_{\mu}(\mathrm{ADF})$ & -2.21 & $(0)$ & -1.35 & $(0)$ & -0.61 & $(0)$ & -1.67 & $(0)$ \\
$\tau(\mathrm{ADF})$ & $-2.80^{*}$ & $(0)$ & 1.81 & $(0)$ & 5.64 & $(0)$ & -1.21 & $(0)$ \\
$\tau_{\mathrm{T}}(\mathrm{PP})$ & $-4.36^{*}$ & $(2)$ & -2.92 & $(0)$ & -2.55 & $(1)$ & -2.03 & $(2)$ \\
$\tau_{\mu}(\mathrm{PP})$ & -2.20 & $(3)$ & -1.31 & $(5)$ & -0.62 & $(1)$ & -1.95 & $(2)$ \\
$\tau(\mathrm{PP})$ & $-2.96^{*}$ & $(3)$ & 5.10 & $(25)$ & 6.25 & $(1)$ & -1.26 & $(1)$
\end{tabular}

Statistics

\begin{tabular}{lllllllll}
$\begin{array}{l}\text { (First } \\
\text { Differences) }\end{array}$ & $\Delta$ lfo & lag & $\Delta$ lfdp & lag & $\Delta$ lgdp & lag & & \\
\hline$\tau_{\mathrm{T}}$ (ADF) & $-7.58^{*}$ & $(0)$ & $-5.56^{*}$ & $(0)$ & $-5.86^{*}$ & $(0)$ & $-4.57^{*}$ & $(0)$ \\
$\tau_{\mu}$ (ADF) & $-7.77^{*}$ & $(0)$ & $-5.68^{*}$ & $(0)$ & $-5.97^{*}$ & $(0)$ & $-4.64^{*}$ & $(0)$ \\
$\tau(\mathrm{ADF})$ & $-7.38^{*}$ & $(0)$ & $-5.25^{*}$ & $(0)$ & $-1.66^{* * *}$ & $(1)$ & $-4.71^{*}$ & $(0)$ \\
$\tau_{\mathrm{T}}(\mathrm{PP})$ & $-9.62^{*}$ & $(6)$ & $-6.29 *$ & $(6)$ & $-5.86^{*}$ & $(0)$ & $-4.56^{*}$ & $(1)$ \\
$\tau_{\mu}(\mathrm{PP})$ & $-9.90^{*}$ & $(6)$ & $-6.32^{*}$ & $(6)$ & $-5.97^{*}$ & $(0)$ & $-4.64^{*}$ & $(1)$ \\
$\tau(\mathrm{PP})$ & $-7.38^{*}$ & $(1)$ & $-5.32^{*}$ & $(2)$ & $-3.11^{*}$ & $(2)$ & $-4.71^{*}$ & $(1)$
\end{tabular}

Note: $\tau_{T}$ represents the model with a drift and trend; $\tau_{\mu}$ is the model with a drift and without trend; $\tau$ is the model without a drift and trend. Lag lengths are chosen by Schwarz Information Criterion (SIC). ${ }^{* * *}$ and ${ }^{* * *}$ denote rejection of the null hypothesis at $1 \%, 5 \%$ and $10 \%$ levels respectively.

Table 2: Critical Values for ARDL Modeling Approach

\begin{tabular}{|c|c|c|c|c|c|c|}
\hline \multirow[b]{2}{*}{$k=2$} & \multicolumn{2}{|c|}{0.10} & \multicolumn{2}{|c|}{0.05} & \multicolumn{2}{|c|}{0.01} \\
\hline & I (0) & I (1) & I (0) & I (1) & I (0) & I (1) \\
\hline $\mathrm{F}_{\mathrm{IV}}$ & 3.38 & 4.02 & 3.88 & 4.61 & 4.99 & 5.85 \\
\hline $\mathrm{F}_{\mathrm{V}}$ & 4.19 & 5.06 & 4.87 & 5.85 & 6.34 & 7.52 \\
\hline $\mathrm{F}_{\text {III }}$ & 3.17 & 4.14 & 3.79 & 4.85 & 5.15 & 6.36 \\
\hline$t_{V}$ & -3.13 & -3.63 & -3.41 & -3.95 & -3.96 & -4.53 \\
\hline $\mathrm{t}_{\text {III }}$ & -2.57 & -3.21 & -2.86 & -3.53 & -3.43 & -4.10 \\
\hline
\end{tabular}

Source: Pesaran et al. (2001): p.300-301 for F-statistics and p.303-304 for t-ratios.

Notes: $\mathrm{k}$ is the number of regressors for dependent variable in ARDL models. $\mathrm{t}_{\mathrm{V}}$ and $\mathrm{t}_{\mathrm{III}}$ are the $\mathrm{t}$ ratios for testing $\sigma_{1 \mathrm{Y}}=0$ and $\varpi_{1 \mathrm{Y}}=0$ respectively with and without deterministic linear trend. 
Table 3. The Bounds Test for Co-integration

\begin{tabular}{|c|c|c|c|c|c|c|}
\hline \multirow[b]{2}{*}{ Variables } & \multicolumn{3}{|c|}{$\begin{array}{c}\text { With } \\
\text { Deterministic Trends }\end{array}$} & \multicolumn{2}{|c|}{$\begin{array}{c}\text { Without } \\
\text { Deterministic Trend }\end{array}$} & \multirow[b]{2}{*}{ Conclusion } \\
\hline & $\mathrm{F}_{\mathrm{IV}}$ & $\mathrm{F}_{\mathrm{V}}$ & $t_{V}$ & $F_{\text {III }}$ & $\mathrm{t}_{\text {III }}$ & \\
\hline (1) FO and FDP & & & & & & $\mathrm{H}_{0}$ \\
\hline $\mathrm{F}_{\mathrm{FO}}(\mathrm{FO} / \mathrm{FDP})$ & $5.89 c$ & $8.56 c$ & $-4.10 c$ & $4.03 \mathrm{~b}$ & $-2.73 b$ & Rejected \\
\hline $\mathrm{F}_{\mathrm{FDP}}(\mathrm{FDP} / \mathrm{FO})$ & $2.50 \mathrm{a}$ & $3.75 a$ & $-2.73 a$ & $1.83 a$ & $-1.91 \mathrm{a}$ & Accepted \\
\hline \multicolumn{7}{|l|}{ (2) FO and GDP } \\
\hline $\mathrm{F}_{\mathrm{FO}}(\mathrm{FO} / \mathrm{GDP})$ & $8.46 c$ & $12.25 c$ & $-4.95 c$ & $12.56 c$ & $-4.92 c$ & Rejected \\
\hline $\mathrm{F}_{\mathrm{GDP}}(\mathrm{GDP} / \mathrm{FO})$ & $3.61 b$ & $5.35 c$ & $-3.04 a$ & $0.15 a$ & $-0.07 a$ & Rejected \\
\hline \multicolumn{7}{|l|}{ (3) FO and v-GDP } \\
\hline $\mathrm{F}_{\mathrm{FO}}(\mathrm{FO} / \mathrm{v}-\mathrm{GDP})$ & $6.36 c$ & $9.23 c$ & $-4.23 c$ & $2.62 \mathrm{a}$ & $-2.26 a$ & Rejected \\
\hline$F_{\mathrm{v}-\mathrm{GDP}}(\mathrm{v}-\mathrm{GDP} / \mathrm{FO})$ & $1.98 \mathrm{a}$ & $2.75 a$ & $-2.15 a$ & $2.93 a$ & $-2.39 a$ & Accepted \\
\hline
\end{tabular}

Table 4: Granger Causality Tests under VECM and VAR model

\section{Lag Level}

Null Hypothesis
12 3 2

(1) FO and FDP

FO does not Granger cause FDP

0.02 FDP does not Granger cause FO

(2) FO and GDP

$\begin{array}{lllllll}\text { FO does not Granger cause GDP } & 0.30 & -2.24^{* * *} & 0.25 & 2.51^{* *} & 0.08 & -2.76^{* * *} \\ \text { GDP does not Granger cause FO } & 3.68^{* * *} & -0.00 & 2.15 & -0.30 & 1.44 & -0.62\end{array}$

(3) FO and v-GDP

FO does not Granger cause v-GDP $\quad 4.77$

$\begin{array}{cl}- & 3.28^{* * *} \\ -0.92 & 2.57\end{array}$

$\begin{array}{cc}- & 2.05 \\ -2.16^{* *} & 1.30\end{array}$

$-1.43$

$\mathrm{FO} \rightarrow \mathrm{v}-\mathrm{GDP}$

Note: $*, * *$ and ${ }^{* * *}$ denote significance respectively at $1 \%, 5 \%$ and $10 \%$ levels. 


\section{UČINAK FINANCIJSKE OTVORENOSTI NA FINANCIJSKI RAZVOJ, RAST I VOLATILNOST U TURSKOJ: DOKAZI DOBIVENI ARDL GRANIČNIM TESTOVIMA}

\section{SAŽETAK}

Cilj ovog rada je istražiti učinak financijske otvorenosti na financijski razvoj, rast $i$ volatilnost $u$ Turskoj. Rezultati graničnog testa (bounds test) otkrivaju da je financijska otvorenost u odnosu dugoročne ravnoteže s financijskim razvojem, rastom $i$ volatilnosti proizvodnje. Grangerov test kauzalnosti pokazuje, dugoročno gledano, postojanje jednosmjerne kauzalnosti od financijskog razvoja do financijske otvorenosti, dok kratkoročno postoji kauzalnost od financijske otvorenosti prema volatilnosti proizvodnje. Ipak, Grangerova kauzalnost se ne otkriva niti od financijske otvorenosti prema rastu, niti od financijske otvorenosti prema financijskom razvoju. Rezultati ukazuju na potrebu za daljnjim financijskim razvojem i savjesnijom monetarnom i fiskalnom politikom usmjerenima na financijsku otvorenost $u$ Turskoj.

Ključne riječi: međunarodna ulaganja, dugoročna kretanja kapitala, kratkoročna kretanja kapitala, makroekonomija otvorenog gospodarstva, gospodarski rast otvorenih gospodarstava, granični test, Grangerova kauzalnost

JEL klasifikacija: F21; F32; F41; F43; C32 